\title{
CLONIDINE IN RESPIRATORY PANIC DISORDER SUBTYPE
}

\author{
Alexandre M. Valença ${ }^{1}$, Antonio E. Nardi ${ }^{1}$, Marco A. Mezzasalma ${ }^{1}$, Isabella Nascimento ${ }^{1}$, Fabiana L. \\ Lopes $^{1}$, Walter A. Zin'², Marcio Versiani'
}

\begin{abstract}
Objective: Clonidine, which inhibits locus coeruleus discharge, would seem for theoretical reasons to be a good antipanic drug. Panic disorder (PD) presents a heterogeneous cluster of symptoms and a classification based on subtypes has been suggested and the respiratory symptoms group appears as a distinct subtype. Method: We report three cases of respiratory PD patients who were successfully treated with clonidine. Results: Patients obtained panic free status, reduced anxiety levels and better functioning after clonidine administration (0.30-0.45 mg/day) for 6 weeks. Conclusion: Clonidine can be effective in the treatment of respiratory PD. This drug might play a role in relieving symptoms of anxiety due to noradrenergic hyperactivity in these patients.
\end{abstract}

KEY WORDS: respiration, panic attack, norepinephrine, panic subtypes, anxiety disorder.

\begin{abstract}
Clonidina no subtipo respiratório de transtorno de pânico
RESUM O - Objetivo: Clonidina, que inibe a descaga do locus coeruleus, parece ser, por razões teóricas, uma boa droga antipânico. 0 transtorno de pânico (TP) apresenta uma constelação heterogênea de sintomas e uma classificação baseada em subtipos tem sido sugerida. 0 grupo com sintomas respiratórios aparece como um subtipo distinto. M étodo: Descrevemos três casos de pacientes com subtipo respiratório de TP tratados de forma bem sucedida com clonidina. Resultados: Os pacientes obtiveram remissão de ataques de pânico, redução dos níveis de ansiedade e melhor funcionamento após administração de clonidina (0,300,45 mg/dia) por 6 semanas. Conclusão: Clonidina pode ser eficaz no tratamento do subtipo respiratório de TP. Esta droga pode ter um papel no alívio de sintomas de ansiedade devidos a hiperatividade noradrenérgica, nestes pacientes.
\end{abstract}

PALAVRAS-CHAVE: respiração, ataque de pânico, norepinefrina, subtipos de pânico, transtorno de ansiedade.

Panic disorder (PD) is a common and potentially debilitating anxiety disorder that can adversely affect patient's personal, social, work, and academic lives ${ }^{1}$. The care of patients with PD involves approaches that are designed to reduce the frequency and severity of panic attacks, reduce morbidity, and improve patient functioning ${ }^{2}$. M odalities for which there is considerable evidence of efficacy in the treatment of PD include cognitive behavioral therapies ${ }^{3}$ and pharmacotherapy. Medications from several classes have been shown to be effective in PD treatment: selective serotonin reuptake inhibitors - SSRI ${ }^{4}$, tricyclic antidepressants ${ }^{5}$ high-potency benzodiazepines ${ }^{6,7}$ and monoamine-oxidase inhibitors - MAO-I ${ }^{8}$. It has been hypothesized that the alpha ${ }_{2}$-adrenergic receptor agonist clonidine also may be useful in the treatment of $P D^{9,10}$.

Clonidine, which inhibits locus coeruleus discharge, would seem for theoretical reasons to be a good antipanic drug. Few clinical trials with clonidine for the treatment of PD have been conducted ${ }^{11,12}$. In a small series two-thirds of patients responded initially but the therapeutic effect tended to be lost in a matter of weeks, despite continuation of dose ${ }^{11}$. Another study confirmed a similar pattern of loss of response during a 10-week trial ${ }^{12}$. This loss of response, plus a number of bothersome side effects, makes clonidine poor initial choice for treatment of panic disorder. How ever, one controlled study found clonidine to be efficacious for both panic disorder and generalized anxiety disorder $(G A D)^{10}$. Clonidine has an FDA-approved indication for the treatment of hypertension. It has been widely studied as a means of blocking physiological symptoms of opioid withdrawal like palpitations and sweating ${ }^{13}$. The drug has also been studied in anxiety and in panic disorder and has been shown to be effective in both, although tolerance to the antianxiety effects frequently develops ${ }^{12}$. It is conceivable that the drug's mixed, partial pre-and postsynaptic receptor agonist properties may enter into the development of tolerance.

Supported by the Brazilian Council for Scientific and Technological Development (CNPq), Grant 300500/93-9: 'Laboratory of Panic \& Respiration, Institute of Psychiatry, Federal University of Rio de Janeiro, Rio de Janeiro RJ Brazil (UFRJ); ' Laboratory of Respiration Physiology, Carlos Chagas Filho Biophysics Institute, UFRJ. 
Clonidine has also been used to test various aspects of the catecholamine hypotheses of affective and anxiety disorders ${ }^{14,15}$.

Our aim is to report three cases of respiratory PD patients who were successfully treated with clonidine in the Laboratory of Panic \& Respiration, which is an anxiety outpatient unity. We obtained written informed consent, and our local ethics committee approved the protocol.

\section{CASES}

Case 1. A 20 years old woman, student, Caucasian. The patient began to have panic attacks three years ago after the end of a romantic relationship. She describes having sweating, shivering, tachycardia, dyspnea and an intense fear that lasted from 5 to 20 minutes. She had two other panic attacks similar to this first one on the following 15 days, but she felt better afterwards. In that occasion she denied depressive symptoms like depressed mood most of the day or marked diminished interest or pleasure in activities. Two months before her first evaluation she began to have new panic attacks with feelings of dyspnea, "shortness of breath" sensation, tachycardia, fear of choking, and fear of dying. She describes that she began to feel frightened of being alone at home and to ride buses or other public transportation, avoiding these situations. She underwent several laboratory exams which all results were normal. She was initially treated with $0.15 \mathrm{mg} / \mathrm{day}$ of clonidine. After 6 weeks she was taking $0.30 \mathrm{mg} /$ day of clonidine and she achieve full remission of the panic attacks and the phobic avoidance. On the two initial weeks she describes feeling mild dizziness and nausea.

Case 2. A 35 years old woman, housewife, Caucasian. The patient began to have panic attacks when she was 10 years old, with nocturnal panic attacks that woke her up. As she told us: "My heart raced, I felt breathless and trembled. I was very afraid that I would die". These panic attacks happened only twice. When she was 18 years old, after her first pregnancy, she began to have nocturnal panic attacks again. These panic attacks were lessened with treatment with an occasional benzodiazepine. There was a 3 to 4 months of interval between panic attacks. She did not look for medical treatment because she thought she had "religious problems". On the third month preceding her first medical evaluation she began to have diurnal and nocturnal panic attacks on a daily basis, describing feelings of tachycardia, dyspnea, trembling, paresthesias and a feeling of imminent death, with a duration between 15 and 30 minutes. Since these panic attacks began she avoided crow ded places and traffic jams, fearful of "feeling sick". She had no anxiety symptoms related to generalized anxiety disorder. Her anxiety symptoms and worry just were related about having panic attacks. She was referred to our service. The clinical and laboratory exams were normal. She was initially treated with $0.15 \mathrm{mg} /$ day of clonidine, which was afterwards increased to $0.45 \mathrm{mg} /$ day of clonidine, with full remission of phobic avoidance and panic attacks after 4 weeks of treatment and this improvement was kept until the sixth week. She describes feeling dizziness and somnolence on the initial 3 weeks of treatment, but these symptoms were not hindering her daily functioning.

Case 3. A 23 years old woman, college student, Caucasian. The patient describes recurrent panic attacks during one-year period, with feelings of dizziness, tachycardia, trembling, heat spells, dysp- nea and fear of going insane, with 10 to 15 minutes duration. This panic attacks happened mainly in closed places, such as restaurants and bookstores. She reported an extreme fear of closed and dark places and was admitted to emergency rooms several times, specially because of cardiac and respiratory panic attack symptoms. She had no pain, gastrointestinal or pseudoneurological symptoms related to somatization disorder. She developed an agoraphobic behavior as she describes that she found out that by avoiding these situations she could decrease the frequency of these panic attacks, and she progressively interrupted all her daily activities, almost without leaving her house at all. Laboratory and clinical exams were normal. She was initially treated with $0.15 \mathrm{mg} /$ day of clonidine, which was increased to $0.30 \mathrm{mg} /$ day after 4 weeks of treatment and which fully remitted her panic attacks. At the 6 th week of her treatment she took back her studies, with the same dosage of $0.30 \mathrm{mg} /$ day of clonidine. She describes feelings of somnolence on the two initial weeks of her treatment.

\section{DISCUSSION}

Our results support previous data of clinical efficacy of clonidine in $\mathrm{PD}^{10-12}$. All the three patients obtained panic free status, reduced anxiety levels and better functioning after clonidine administration for 6 weeks. An interesting finding was the remission of panic attacks with clonidine, which occurred as early as the fourth week of treatment. It was also found that tolerance rapidly developed to sedation but not to the anxiolytic properties during the six weeks of the follow-up. Clonidine was well tolerated by patients and the side-effects reported (dizziness, somnolence and nausea) were similar to that present in other studies ${ }^{10,12}$. All patients were classified as respiratory panic disorder subtype, according to Briggs et al. criteria ${ }^{16}$. This subtype is a distinct one, presenting more scientific evidence than any other group ${ }^{17}$ and may have favorable clinical response to clonidine.

Clonidine is known to block alpha-2 receptors in the locus coeruleus, which has the highest concentrations of norepinephrine in the central nervous system and is a very important site in the mediation of anxiety ${ }^{18,19}$. Clonidine has been found to decrease acutely ratings of anxiety in PD patients, when administered intravenously in single doses of $1.5-2.0 \mu \mathrm{g} / \mathrm{kg}$. In a study, Nutt ${ }^{20}$ observed that the administration of $1.5 \mu \mathrm{g} / \mathrm{kg}$ of clonidine in 16 PD patients led to a fall in anxiety. In other study, Charney et al. ${ }^{21}$ found that the administration of $2.0 \mu \mathrm{g} / \mathrm{kg}$ of clonidine reduced anxiety after 15 to 30 minutes in 38 PD patients. Uhde et al. ${ }^{12}$ also observed that the administration of $1.5 \mu \mathrm{g} / \mathrm{kg}$ of clonidine reduced anxiety in 18 PD patients.

Some short-term studies with clonidine in $\mathrm{PD}^{10-13}$ and other anxiety disorders ${ }^{22,23}$ have been conducted. An eight-week open trial by Liebowitz et al. ${ }^{11}$ of 11 PD patients, using clonidine to a maximal dose of $1 \mathrm{mg} /$ day, showed four subjects to have a good antipanic response at dosages varying from 0.2 to $0.5 \mathrm{mg} /$ day. Four other patients had transient responses and three subjects could not tolerate increasing doses in attempts 
to achieve therapeutic benefit. All subjects suffered bothersome side-effects, including sedation, fatigue and loss of motivation.

In a four-week double-blind placebo cross-over study, Hoehn-Saric et al. ${ }^{10}$ examined the effect of clonidine on 14 PD and 9 generalized anxiety disorder (GAD) patients. Patients received a starting dose of clonidine $0.2 \mathrm{mg} /$ day. After one week the dosage was adjusted to $0.2-0.5 \mathrm{mg}$ according to patient response and tolerance. The condition of four of the 23 patients(three with PD and one with GAD) worsened with clonidine and the drug treatment had to be discontinued. Five patients (three with PD and two with GAD) found clonidine more helpful than other medications and became free of symptoms. The remaining 14 patients felt somewhat better with clonidine than with placebo but less well than with conventional anxiolytic medications.

In a cross-over study by Ko et al. ${ }^{13}$, of six PD patients who were treated for four weeks with placebo, clonidine (4-5 $\mu / \mathrm{kg} /$ day) and imipramine (100mg/day), clonidine was found to be more effective than imipramine in reducing anxiety stimulated by phobic exposure.

In conclusion this study indicates that clonidine can be effective in the treatment of respiratory PD. Because of its specific adrenergic action, clonidine may be an effective tool for investigating and elucidating abnormalities in noradrenergic system in PD. This drug might play a role in relieving symptoms of anxiety due to noradrenergic hyperactivity.

\section{REFERENCES}

1. Almeida YA, Nardi AE. Psychological features in panic disorder. Arq Neuropsiquiatr 2002;60:553-557.

2. American Psychiatric Association. Practice guideline for the treatment of patients with panic disorder. Washington, DC, 1998:1-73.

3. Barlow DH. Cognitive-behavioral therapy for panic disorder: current status. J Clin Psychiatry 1997;58(Suppl 2):32-37.

4. Pollack MH, Marzol PC. Panic: course, complications and treatment of panic disorder. J Psychopharmacol 2000;14(Suppl 1):25-30.

5. Mavissakalian M, Perel JM. Imipramine in panic disorder with agoraphobia: dose ranging and plasma level-response relationships. Am J Psychiatry 1995;152:673-682.

6. Valença AM, Nardi AE, Nascimento I, Mezzasalma MA, Lopes FL, Zin WA. Double-blind clonazepam vs placebo in panic disorder treatment. Arq Neuropsiquiatr 2000;58:1025-1029.

7. Valença AM, Nardi AE, Nascimento I, Zin W A, Versiani M. Carbon dioxide test as an additional clinical measure of treatment response in panic disorder. Arq Neuropsiquiatr 2002;60:358-361.

8. Tiller JW, Bouwer C, Behnke K. Moclobemide for anxiety disorders: a focus on moclobemide for panic disorder. Int Clin Psychopharmacol 1997;12 (Suppl 6):27-30.

9. Charney DS, Heninger GR. Abnormal regulation of noradrenergic function in panic disorders. Arch Gen Psychiatry 1986;43:1042-1053.

10. Hoehn-Saric R, Merchant AF, Keyser ML, Smith VK. Effects of clonidine on anxiety disorders. Arch Gen Psychiatry 1981;38:1278-1282.

11. Liebowitz MR, Fyer AJ, Mcgrath P, Klein DF. Clonidine treatment of panic disorder. Psychopharmacol Bull 1981;17:122-123.

12. Uhde TW, Stein MB, Vittone BJ, et al. Behavioral and physiologic effects of short-term and long-term administration of clonidine in panic disorder. Arch Gen Psychiatry 1989;46:170-177.

13. Ko GN, Elsworth J, Roth RH, Rifkin BG, Leigh H, Redmond E. Panicinduced elevation of plasma MHPG levels in phobic-anxious patients. Arch Gen Psychiatry 1983;40:425-430.

14. Coplan JD, Liebowitz MR, Gorman JM, et al. Noradrenergic function in panic disorder: effects of intravenous clonidine pretreatment on lac- tate induced panic. Biol Psychiatry 1992;31:135-146.

15. Coplan JD, Pine DS, Papp LA, Gorman JM. A view on noradrenergic hypothalamic-pituitary-adrenal axis and extrahypothalamic corticotrophin-releasing factor function in anxiety and affective disorders: the reduced growth hormone response to clonidine. Psychopharmacol Bull 1997;33:193-201.

16. Briggs AC, Stretch DD, Brandon S. Subtyping of panic disorder by symptom profile. Br J Psychiatry 1993;163:201-209.

17. Lopes F L, Nardi A E, Nascimento I, Valença AM, Zin W A. Nocturnal panic attacks. Arq Neuropsiquiatr 2002;60:717-720.

18. Andreatini R, Blanchard C, Blanchard R, et al. The brain decade in debate: II. Panic or anxiety? From animal models to a neurobiological basis. Braz J Med Biol Res 2001;34:145-154.

19. Gorman JM, Kent JM, Sullivan GM, Coplan JD. Neuroanatomical hypothesis of panic disorder, revised. Am J Psychiatry 2000;157:493-505.

20. Nutt DJ. Altered central $\alpha_{2}$ - adrenoceptor sensitivity in panic disorder. Arch Gen Psychiatry 1989;46:165-169.

21. Charney DS, Woods SW, Krystal JH, Nagy LM, Heninger GR. Noradrenergic neuronal dysregulation in panic disorder: the effects of intravenous yohimbine and clonidine in panic disorder patients. Acta Psychiatr Scand 1992;86:273-282.

22. Kinzie DJ, Leung P. Clonidine in Cambodian patients with posttraumatic stress disorder. J Nerv Ment Dis 1989;177:546-550.

23. Goldstein S. Treatment of social phobia with clonidine. Biol Psychiatry 1987;22:369-372. 